\title{
Fiction Stories and Poster Presentation in Teaching Indonesian EFL Students
}

\author{
Asmi Rusmanayanti \\ English Department \\ Faculty of Teacher Training and Education \\ Lambung Mangkurat University, Banjarmasin, Indonesia
}

\begin{abstract}
Literacy is a crucial topic for most countries around the globe. As in Indonesia, literacy becomes a major issue since most of young Indonesian people decrease their tendency of reading books in their free time. Reading, either it is extensive or intensive ones, is an essential knowledge for everyone. Fictions are needed to be explored for better literacy. As English as a Foreign Language (EFL) students, English fiction is one of a good source to improve students ability in using English. By reading more fictions, EFL students can gain many benefits directly or indirectly to their English, and it can be seen easily from their fluency by using a special model named Poster Presentation. Furthermore, poster presentation can be used in teaching and learning as variations in reading activity. This research is to explore the use of fiction stories and Poster Presentations for Indonesian EFL students at Lambung Mangkurat University. There were some stages during the Fiction stories and poster presentation project which involved tutoring, group work, and the poster presentation. The students were asked to read short fiction stories, make a summary of it, and finally design the summary into posters. The tutoring part was beneficial to keep students understand the project. The questionnaire by using Likert-scale was distributed which to investigate students' perception on the use of poster presentation in learning fiction stories. The results showed that the students interpret poster presentation to improve their reading comprehension, communication, cooperation, collaboration, and creativity during the classroom interaction.
\end{abstract}

Keywords: Extensive reading, fiction stories, poster presentation, reading comprehension

Cite as: Rusmanayanti, A. (2019). Fiction Stories and Poster Presentation in Teaching Indonesian EFL Students. Arab World English Journal for Translation \& Literary Studies, 3 (2) 78-90.

DOI: http://dx.doi.org/10.24093/awejtls/vol3no2.8 


\section{Introduction}

\section{Background of the study}

Reading is one of the four skills that hold big roles in learning English. It is a skill that is essential for students because it influences their ability in English communication. For reading is a skill that could be used to gain information and to gain access to alternative explanations, whether it is for work or study. Teaching reading in Indonesia is classified into teaching reading comprehension, and according to snow (2002), reading comprehension is the process of simultaneously extracting and constructing meaning through interaction and involvement with written language.

Considering the importance of reading comprehension, it is highly recommended for teachers to teach reading using things which motivate students. Extensive reading is one of them since it is a situation when students read extensively, they read very easy, and also could enjoy their reading material. It is also regarded as beneficial activity to give rich input for students' language development. Furthermore, to make extensive reading more interesting for students, poster presentation can be integrated as the variation in the reading activity since using media is one of the ways to motivate students in teaching reading progress.

\section{The objective of the study}

This study aimed to investigate students' perception on the use of poster presentation in learning fiction stories.

\section{The Scope of the Study}

The scope of the study is intended for the Extensive Reading class that it is held at Lambung Mangkurat University. The focus of this research is to find out students' perception on the use of poster presentation in learning fiction stories.

\section{The Significance of the Study}

This research is expected to give an input on teaching and learning about fiction stories for Indonesian EFL students, especially about information related to the usage of poster presentation in Extensive Reading class. The result of this research also expected to be an additional source, especially to another researcher who wants to conduct research on the same topic, either at the same level or different level.

\section{Literature Review}

\section{Poster Presentations}

According to Yale Center of Teaching and Learning, ctl.yale.edu (2018), posters are tools that enable visualization in the classroom to foster student learning. While a poster presentation, according to Handron, as cited in Bracher, et. al (1998), is an experiential learning activity that stimulates curiosity and interest, encourages exploration and integration of concepts and provides students with a novel way of demonstrating understanding. Thus, it is a condition where the presenter combines text and graphics to make a visually pleasing presentation (Kiefer, et. al, 2012). This presentation can take place in one large room, several smaller rooms, or even on a balcony. 
Hence, as their visitors walk by, the poster should quickly and efficiently communicate the points which the presenters want to tell. Unlike the fast pace of a slide show, a poster presentation allows the visitors to study and restudy the information and discuss it directly with the presenter. Furthermore, there are many advantages of using posters; in this case, poster presentation; as a visual aid in the learning process (Print MePoster.com, 2018), those are:

a. It's an effective way to catch and hold the attention of pupils or students as well as maintain their interest in the subject.

b. Posters can motivate students to learn a specific topic.

c. They can help learners to focus on a certain idea, fact, event or process.

d. They are convenient both for pupils and teachers as they help students to absorb the material faster.

e. Images are more "evocative" than words and can lay the foundation of a variety of associations.

f. $65 \%$ of people worldwide find learning most effective when it is transmitted visually and a poster is one of the best ways to do that.

g. By having a poster in the classroom, you induce the students to constant learning, even if they just look around the classroom.

Thus, according to explanations above, posters provide an opportunity to pair visual learning with textbook reading, lecture, and traditional homework assignments. As such, posters are often created by students to visually display a significant course project, developing research, or a particular perspective for class to consider.Moreover, such practices have been shown to improve metacognitive practice too (Logan, et. al, 2015).

\section{Extensive Reading}

According to ERF (2011), extensive reading is a situation when students read extensively, they read very easy, enjoyable books to build their reading speed and reading fluency. Extensive Reading aims to help the student to be better at their reading skill rather than reading to study the language itself.

\section{Genres of Literature}

There are many genres of literature which can be read, but all of them can be categorized into two, which is non-fiction and fiction. According to Einstein (2003), non-fiction is a type of literature which tell the reader about something really happen, to be exact, tell about several facts. It is also in line with statementfrom Harvey and Goudvis (2000) who says that one of the most important goal of non-fiction is to answer specific question. Thus, non-fiction is usually written with specific, or specialized, text features and text structures. There are several types of non-fiction that mostly read by people, they are letters, articles, editorials, speeches, brochures, biographies, essays, academic journals, etc.

As for fiction, according to Literarydevices.net (2013), fiction consist of many kinds of stories such as dramas, novels, and the likes which based on fabricated or made-up stories 
characters and can represent symbolic or thematic features - known as literary merits. The aim of a fiction story more than simply a story. It comments on something substantial to social, politics, human issues, and the like.There are many types of literature which can be considered as fiction, there are romance, science fiction, horror, thriller, etc.

1. Romance

According to Romance Writer of America (2018), Romance is a genre which hastwo basic elements, a central love story and an emotionally satisfying ending. Beyond that, romance novels or short stories may have any tone or style, which can be set in any place or time, and have varying levels of sensuality - ranging from sweet to extremely hot. An example of romance story is Romeo and Juliet by William Shakespeare.

2. Science Fiction

Science fiction is a genre of fiction in which the stories often tell about science and technology of the future (Read Write Think, 2005). Even though it considered fiction, it is important to note that science fiction has a relationship with the principles of science. Thus, this kind of stories involve partially true partially fictitious laws or theories of science. An example of science fiction story is The Time Machine by H. G. Wells.

3. Horror

According to Cuddon (1984), has defined the horror story as "a piece of fiction in prose of variable length... which shocks or even frightens the reader, or perhaps induces a feeling of repulsion or loathing ". Thus, it can be concluded that horror is a genre which is intended to, or has the capacity to frighten, scare, disgust, or startle its readers or viewers by producing feelings of horror and terror. An example of horror story is Dracula by Bram Stoker.

4. Thriller

Thrillers could be stated as the mood of suspenseful excitement. Thus, thriller as defined as thrills. According to Patterson (2006) Thrillers could be provided as a rich literary feast. The kinds of thrillers such as Spy Thriller, The Legal Thriller, Medical Thriller, Action-adventure Thriller, Political Thriller, Religious Thriller, Military Thriller and High-tech Thriller. Those Genres should have several characteristics in terms of creating an emotion in each genres. Therefore, It should have a thrill to be a good thriller.

The story of thriller which is broadly known is The Da Vinci Code by Dan Brown. Other famous stories which considered as a thriller are stories written by Stephen King. 


\section{Reading Comprehension}

Wooley(2011) states that reading comprehension is a process to gain understanding through describing of meaningful text. To gain an overall understanding of text in a meaningfulway, the readers need to integrate the meaning of successive sentences, to establish the local coherence and to establish of how the informations fits together as a whole or global coherence. For both local and global coherence, the readers need to incorporate background knowledge to make sense of details that are only implicit. The interaction is done by decoding words and using background knowledge to get an understanding of the writer message. Based on the two explanation above, It can be concluded that background knowledge plays important role in achieving comprehension. This idea also supported by Anderson and Pearson in as cited in Hudson (2007), who noted that the interaction of new information with background knowledge is meant by comprehension.

\section{The Methodology of the Research Participants}

This study involved 61 fifth semester students who took Extensive Reading course in Lambung Mangkurat University, Banjarmasin, Indonesia. The students were from two different classes.

\section{The Procedure of the study}

The topic in Extensive Reading course used in this study was fiction short story. The students were given some choices of genres of fiction short story and were asked to vote which genre they wanted to read, namely romance short fiction story, science-fiction short fiction story, and horror/thriller short fiction story. Both classes voted horror/thriller short fiction storythe most.

The students from each class were divided into eight groups consisting of three to four students. The groups were given a poster presentation project which involved tutoring, group work, and the poster presentation itself. The students in their groups were asked to read a short story they chose and they had to understand the story well.Afterwards, they were required to make a summary of the story, and put the summary as well as design it into a poster. The title of the short fiction storythey selected was informed to the lecturer. The allotted time for both extensive reading and poster making is two weeks.

To keep the students on the right track while doing the project, the tutoring activity was conducted by the researchers outside the Extensive Reading course schedule. The tutoring activity was equipped with a record form to monitor the groups' progress. The aspects of the groups' progress that were monitored were as follows:

1. Reading the selected short story (knowing topic, characters, gist of the story)

2. Making a summary of the short story (exposition, raising action, climax, falling action, resolution)

3. Identifying the moral values from the story

4. Making poster

Arab World English Journal for Translation \& Literary Studies 
The tutoring activity was done for maximum four times within two weeks before the deadline of the project. In the tutoring, the student groups reported their progress on the aspects in the record form of tutoring activity and. The tutor might do discussion with the students about their progressive work. The students also got feedback from the tutors related to their work.

Here is the guideline in designing the poster:

1. Word limit of the summary is 250 words.

2. The images can be drawn by the students themselves or taken from other sources like magazine and the Internet which are considered relevant to the story.

3. The general structure of the poster is given, yet the students are allowed to modify it by using their creativity.

4. At the end of the summary, the students need to write the moral value of the short story.

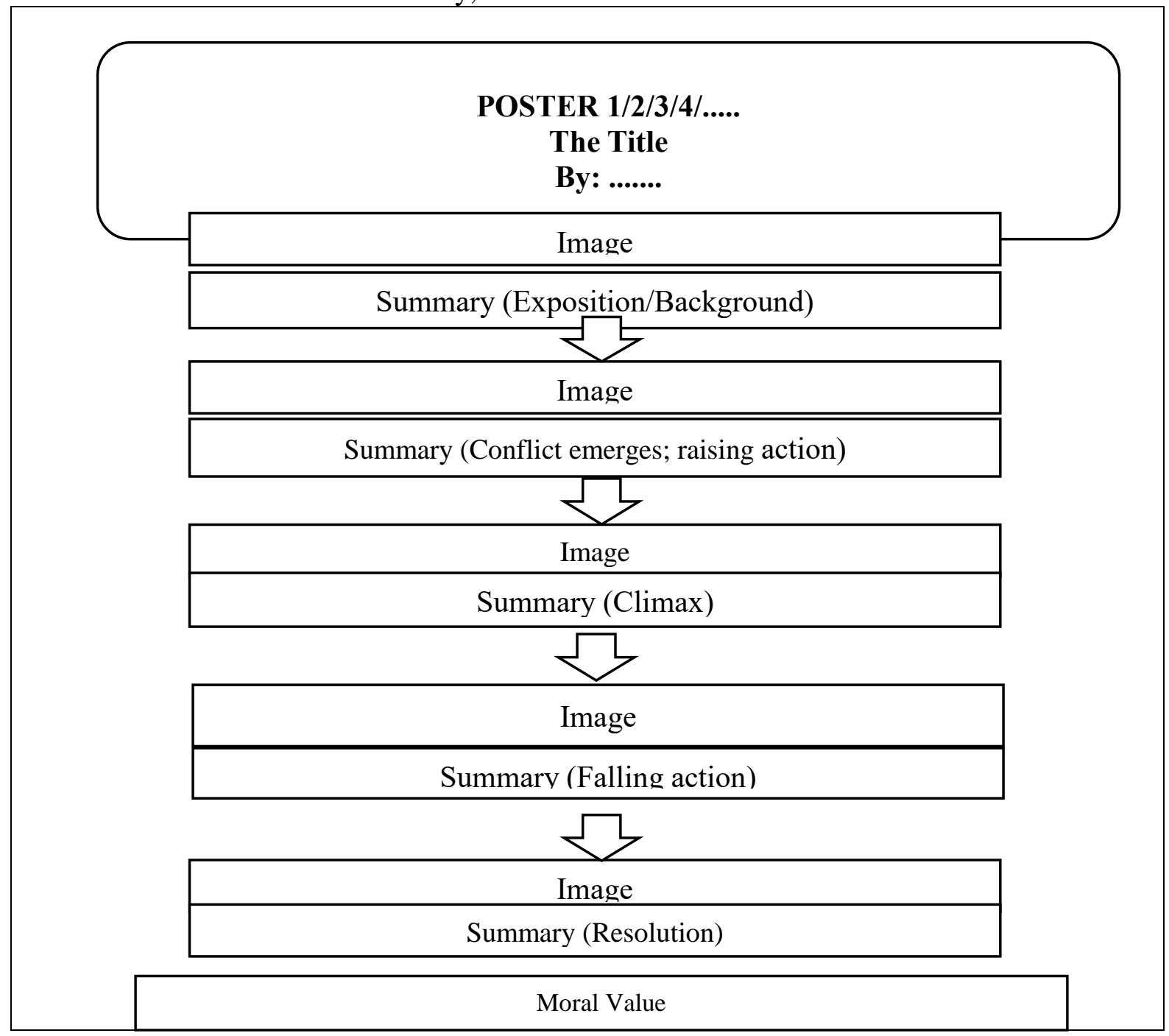

Figure 1. The Comparison of the Changes in Average Scores of Pre-Test and Post-Test between the Experimental and the Control Group

Arab World English Journal for Translation \& Literary Studies 
After two weeks since the project was given, the poster presentation was held during Extensive Reading course schedule. This session consisted of five rounds and each round had 15 minutes. In each round, some members of each group should stay close to their poster and the other members should visit other groups' poster. One of the representatives of each group presented the poster and did storytelling according to the summary they made to the visitors from the other groups. The students who visited the poster should listened to story and were required to ask questions related to the poster or the story. After the five rounds were finished, the remaining 25 minute time was used as the feedback session.

After the whole project was finished, the students were asked to fill a questionnaire about their perception on the project. The major components of this questionnaire include tutoring, group work, and poster presentation. The questionnaire consisted of two parts. Part one consisted of 11 items, while the part two consisted of five open-ended items. For part one, the students gave their perception on each statement of the questionnaire by ticking option 'Strongly agree', 'Agree', 'Undecided', 'Disagree', or 'Strongly Disagree'. For part II, the students were requested to explain their own answer.

\section{Research Results and Discussion}

\section{First component of Part I: Tutoring}

Table 1. The result of questionnaire related to tutoring

\begin{tabular}{|c|c|c|c|c|c|}
\hline & \multicolumn{5}{|c|}{ Percentage of Students' Responses } \\
\hline Questionnaire items & $\begin{array}{c}\text { Strongly } \\
\text { Agree }\end{array}$ & Agree & Undecided & Disagree & $\begin{array}{l}\text { Strongly } \\
\text { Disagree }\end{array}$ \\
\hline \multicolumn{6}{|l|}{ Tutoring } \\
\hline $\begin{array}{l}\text { 1. Tutoring activities help me to } \\
\text { check my comprehension of the } \\
\text { short story. }\end{array}$ & $55.74 \%$ & $40.98 \%$ & $3.28 \%$ & $0 \%$ & $0 \%$ \\
\hline $\begin{array}{l}\text { 2. Tutoring activities provide } \\
\text { useful feedback to my group's } \\
\text { summary and the formulation of } \\
\text { the moral value of the story. }\end{array}$ & $47.54 \%$ & $50.82 \%$ & $1.64 \%$ & $0 \%$ & $0 \%$ \\
\hline $\begin{array}{l}\text { 3. Tutoring activities provide } \\
\text { useful feedback to my group's } \\
\text { poster design. }\end{array}$ & $29.51 \%$ & $54.10 \%$ & $13.11 \%$ & $3.28 \%$ & $0 \%$ \\
\hline
\end{tabular}

The data of students' responses on tutoring activity as the first component of Part I showed that the students had positive perception on tutoring activity since the majority of the students considered that the activity helped them to check their understanding of the the short story and gave them useful feedback to complete the project. This finding is also supported by the results of students' responses for the first open-ended item which is related to their opinion about the tutoring activities you have experienced while doing the task of extensive reading and poster making. Some of the sample answers from the students are as follows:

Arab World English Journal for Translation \& Literary Studies 
1. In my opinion, it's really helpful. We used to be confused and got problem in determining few parts of the summaary, yet the tutor helped us and gave us solution.

2. I think the tutoring was helpful to solve our group problem when we got confused to make the summary.

3. The tutoring activity helps us to make the summary easier to understand. The feedback that we got was very useful.

4. It is really fun. We can discuss it with our tutor and it makes the story easier to understand.

5. I think tutoring activity and poster making are more fun than ordinary short story assignment.

Although most of the students showed their positive perception, there were few students (3.28\%) who stated that they disagreed that tutoring activities provide useful feedback to their group's poster design (item No. 3). It might be due to our intention to let their creativity play major role in designing the poster, so the students felt that feedback on poster design was not given much.

Second component of Part I: Group work

Table 2. The result of questionnaire related to group work

\begin{tabular}{|l|c|c|c|c|c|}
\hline \multicolumn{1}{|c|}{ Questionnaire items } & $\begin{array}{c}\text { Strongly } \\
\text { Agree }\end{array}$ & Agree & Undecided & Disagree & $\begin{array}{c}\text { Strongly } \\
\text { Disagree }\end{array}$ \\
\hline Group Work & \multicolumn{5}{|c|}{ Percentage of Students' Responses } \\
\hline $\begin{array}{l}\text { 4. The group work on the } \\
\text { extensive reading and poster } \\
\text { making helps me understand the } \\
\text { short story more easily. }\end{array}$ & $57.38 \%$ & $37.70 \%$ & $1.64 \%$ & $3.28 \%$ & $0 \%$ \\
\hline $\begin{array}{l}\text { 5. During the group work, I learn } \\
\text { how to make a summary: selecting } \\
\text { main ideas and eliminating } \\
\text { unnecessary details. }\end{array}$ & $40.98 \%$ & $49.18 \%$ & $9.84 \%$ & $0 \%$ & $0 \%$ \\
\hline $\begin{array}{l}\text { 6. The group work enables me to } \\
\text { be engaged in communication, } \\
\text { collaboration, cooperation and } \\
\text { creativity to finish all the tasks. }\end{array}$ & $54.10 \%$ & $34.43 \%$ & $9.84 \%$ & $1.64 \%$ & $0 \%$ \\
\hline
\end{tabular}

Similar to the finding from tutoring component, the students' responses for group work component was also mostly positive. The majority of the students considered the group work beneficial for them in helping them understand the short story easier, finishing the project, and engaging in communication, collaboration, cooperation and creativity to finish all the tasks. The results of students' responses for the open-ended item related to group work also confirm the students' positive perception. It can be seen from the following samples of students' answers.

1. I think group work is really needed and from my experience we learn how to find ideas together, work together or even find the solution for obstacles that we had in the process of making a poster.

Arab World English Journal for Translation \& Literary Studies 
2. It was interesting. I could share the idea. We got a lot of different opinions, but it made our ideas develop.

3. I have to say thanks to my group, with our teamwork we can finish our task no matter what is the result. I am so happy and I do not regret what we do for this poster.

4. I think the group work is so effective to make us understand about extensive reading task and also effiicient.

5. The group work is fun and we can learn more and learn together when doing the task. It develops our creativity.

The small percentage of disagreement responses was also found in the group work component. From the students' responses, it was found that the students who showed disagreement preferred individual work rather than group work. The other response stated that the students encountered disagreement among their group members in doing the project.Moreover, this negative response might be also caused by the absence of particular student's participationin doing the project as indicated by a student's response "The group work is fun because I got more ideas from my peers and it made me have more courage to do better.

However, when I work in the group, there are some students who do not participate." This suggest that the group work will give more optimal benefits if there is equal participation from each member of the group.

\section{Third componentcomponent of Part I: Poster Presentation}

Table 3. The result of questionnaire related to poster presentation

\begin{tabular}{|c|c|c|c|c|c|}
\hline & \multicolumn{5}{|c|}{ Percentage of Students' Responses } \\
\hline Questionnaire items & $\begin{array}{l}\text { Strongly } \\
\text { Agree }\end{array}$ & Agree & Undecided & Disagree & $\begin{array}{l}\text { Strongly } \\
\text { Disagree }\end{array}$ \\
\hline \multicolumn{6}{|l|}{ Poster Presentation } \\
\hline $\begin{array}{l}\text { 7. Poster presentation facilitates me } \\
\text { to demonstrate my comprehension } \\
\text { of the short story. }\end{array}$ & $52.46 \%$ & $42.62 \%$ & $4.92 \%$ & $0 \%$ & $0 \%$ \\
\hline $\begin{array}{l}\text { 8. During poster presentation, I can } \\
\text { practice my speaking skill. }\end{array}$ & $85.25 \%$ & $11.48 \%$ & $3.28 \%$ & $0 \%$ & $0 \%$ \\
\hline $\begin{array}{l}\text { 9. A conducive classroom } \\
\text { interaction among the students is } \\
\text { created during the poster } \\
\text { presentation }\end{array}$ & $44.26 \%$ & $39.34 \%$ & $13.12 \%$ & $3.28 \%$ & $0 \%$ \\
\hline $\begin{array}{l}\text { 10. During poster presentation, I } \\
\text { can improve my comprehension on } \\
\text { plot of various short stories. }\end{array}$ & $44.26 \%$ & $50.82 \%$ & $3.28 \%$ & $1.64 \%$ & $0 \%$ \\
\hline $\begin{array}{l}\text { 11. During poster presentation, I } \\
\text { learn various useful moral values } \\
\text { from other groups. }\end{array}$ & $60.66 \%$ & $32.79 \%$ & $6.56 \%$ & $0 \%$ & $0 \%$ \\
\hline
\end{tabular}

Arab World English Journal for Translation \& Literary Studies 
For the third component of Part I in the questionnaire, the students also showed positive perception on poster presentation. It means that the majority of the students thought that they obtained benefits from poster presentation in demonstrating their comprehension of the short story, practicing their speaking skill, having conducive classroom interaction, improving their comprehension and learning various moral values for daily life. The students' positive perception on poster presentation was further supported by their responses on open-ended question related to poster presentation. It can be seen in the following samples of students' answers:

1. It helps us to practice speaking in English. I become braver to speak (in English).

2. In my opinion, poster presentation gives us deeper understanding than just read short story and make a summary. I personally like the time of explaining my own story and listen to other stories.

3. It helps us to improve our confidence to speak in front of people and think critically about other posters, for example, by asking questions.

4. It's really interesting. I learn how to present confidently in front of my friend, and listen to the other group' presentation.

5. It was great. I could explain my story happily. I was so enthusiastic to present my poster and excited too. In addition, I got many stories from my friends' poster.

Some students who showed their disagreement on the questionnaire items no 9 (A conducive classroom interaction among the students is created during the poster presentation) and 10 (During poster presentation, I can improve my comprehension on plot of various short stories) explained that the poster presentation had limited time, so they felt that the benefits of poster presentation related to the questionnaire items were not optimal. Some of them also stated that they did not have enough time to ask questions to other groups because of the limited time. Moreover, the room to conduct poster presentation was not big enough, so it resulted in difficulties in moving from one group to another and listening to the other groups' story since each representative told the story at one time. These students' responses will be used as constructive feedback for the betterment of poster presentation activity in the future.

\section{Second Component: Whole Task (group work on extensive reading, tutoring, \& poster presentation)}

The results of the next open-ended question revealed thatall of the students consider that the whole task (group work on extensive reading, tutoring, \& poster presentation) is fun and interesting.

It is evident from the following samples of students' answers:

1. Yes. It develops team work. In group, we worked and helped each other. While in tutoring, we got new knowledge or additional knowledge. At the end, in the poster presentation, we were really excited in presenting our work.

2. Yes. Because if the short story is just told by usual/ordinary presentation, it makes us so bored. However, if we have group work like this, we want longer time of study.

Arab World English Journal for Translation \& Literary Studies 
3. Yes, because we were guided from the beginning until the end. We could share our ideas and got feedback.

4. Yes, because it is more fun to read through poster rather than just a plain sheet of paper. It is more interesting. Tutoring also helps us to make a good poster and to learn how to summarize a story and to take the moral value of the story we have read.

5. Yes, because it improves so much on the group work, makes us respect others' opinion, and help us to understand more about the story.

The results of the last open-ended question showed that all of the students prefer the project (group work on extensive reading, tutoring, \& poster presentation) to the other activities/tasks/strategies previously used by their lecturer. Here are some samples of students' answers:

1. Yes, because the other activities are kind of boring for us. We have the class at 1 p.m., so we often feel sleepy during the class.

2. Yes, it is more chalenging than the ordinary extensive reading assignment.

3. Yes, because this way is more fun, more enjoyable, and can give me more experience.

4. Yes, I prefer having the project of poster presentation rather than just presenting the stories using PowerPoint.

5. Yes, it is more interesting and fun than we just sit in the class and listen to the lecturer. It will improve so much, I guess.

Furthermore, there were 2 students who gave suggestion in addition to their preference of the whole project.

1. I think doing the project of poster presentation once is enough for all of us college schedule this semester is so hectic. It was fun, but to do it again for the second time, I am not sure I will be excited. The project may be given once or twice as the variation of our activities.

2. Yes, I prefer this one because it is communicative and trains us to be creative and it's fun, but I don't suggest this whole task to be implemented too often. Afterall, this whole task is interesting.

\section{Conclusion and Suggestions \\ Conclusion}

The results revealed that the students perceived the whole project of poster presentation in learning short fiction stories to be beneficial in improving their reading comprehension, classroom interaction, communication, collaboration, cooperation and creativity of the students. Poster presentation can also be integrated in extensive reading class with tutoring and group work to enhance its benefits. It can also be used as variation or complementary activity in Extensive Reading course.Improvement of the poster presentation project in the future based on the feedback found in students' responses: managing sufficient time allocation for conducting poster presentation (presenting the poster, retelling the story, asking questions to other groups' presentation), providing enough space for poster presentation, and ensuring equal participation from each member of each group.

Arab World English Journal for Translation \& Literary Studies 
AWEJ for Translation \& Literary Studies Volume, 3 Number 2. May 2019

Fiction Stories and Poster Presentation

Rusmanayanti

\section{Suggestions}

Since the research revealed that the students perceived the poster presentation project to be beneficial, therefore it is suggested to be applied in teaching and learning process of extensive reading, especially in learning short-fiction stories. It is also suggested to be implemented in learning other English skill such as writing and speaking.

\section{About the Author:}

Asmi Rusmanyanti is a lecturer at English Education Department, Faculty of Tacher Training and Education, Lambung Mangkurat University. She obtained her bachelor degree at Lambung Mangkurat University and continued her Master degree et Educational Effectiveness and Instructional Design at Groningen University, Netherland. https://orcid.org/0000-0001-6795-9804

\section{References}

Bracher, L., Cantrell, J., \& Wilkie, K. (1998). The Process of Poster Presentation: A Valuable Learning Experience. Medical Teacher, 20 (6) 552-557.

Cuddon, J.A. (1984). The Penguin Book of Horror Stories. Harmondsworth: Penguin. p. 11.

Definition of Science Fiction. (2005). ReadWriteThink. Retrieved February 6, 2018 from http://www.readwritethink.org/files/resources/lesson_images/lesson927/SciFiDefinition. pdf

Einstein, C. (2003). Activating Comprehension: Non-Fiction in the Classroom. EPS Update, the electronic newsletter from Education Publication Service. Retrieved August 10, 2018 fromhttp://eps.schoolspecialty.com/EPS/media/Site-

Resources/downloads/articles/nonfiction.pdf

Guide to Extensive Reading. (2011). The Extensive Reading Foundation. Retrieved February 6, 2018 from http://erfoundation.org/ERF_Guide.pdf

Harvey, S., \& Goudvis, A. (2000). Strategies that work: Teaching comprehension to enhance understanding. Portland, ME: Stenhouse Publishers.

Hudson, T. T. (2007). Teaching Second Language Reading. New York: Oxford University Press.

Implementing Posters in the Classroom. (n.d.). Yale. Retrieved January 26, 2018 from https://ctl.yale.edu/ImplementingPosters

Kiefer, K., Palmquist, M., Barnes, L., Levine, M., \& Zimmerman, D. (2012). Poster Sessions. Writing@CSU. Colorado State University. Retrieved February 6, 2018 from https://writing.colostate.edu/guides/guide.cfm?guideid=78.

Literary Devices Editors. (2013). Fiction. Retrieved August 10, 2018 from https://literarydevices.net/fiction/.

Logan, J., Quinones, R., \& Sunderland, D. (2015). Poster Presentations: Turning a Lab of the Week into a Culminating Experience. Journal of Chemical Education. 92 (1) 96-101.

Patterson, J. (2006). Thriller. Ontario, Canada: MIRA Books (2006) p. iii.

Romance Subgenres. (n.d.). Romance writer of America. Retrieved February 6, 2018 from https://www.rwa.org/p/cm/ld/fid=579.

Arab World English Journal for Translation \& Literary Studies 
AWEJ for Translation \& Literary Studies Volume, 3 Number 2. May 2019

Snow, C. E. (2002). Reading for Understanding Toward an R\&D Program in Reading Comprehension. Santa Monica: RAND. Retrieved March. 07, 2017 from www.rand.org/content/dam/rand/pubs/monograph_reports/2005/MR1465.pdf

The Use of Posters in Education. (n.d.). PrintMePoster.com. Retrieved January 26, 2018 fromhttps://printmeposter.com/blog/the-use-of-posters-in-education

Wooley, G. (2011). Reading Comprehension: Assisting Children with Learning Difficulties. New York: Springer.

Yale Center of Teaching and Learning. (2018). ctl.yale.edu. 